\title{
Expression of Multidimensional Identities in the Post-truth World: Innate Identities in Saramago's Blindness
}

\author{
Joby Joseph ${ }^{1} \&$ Catherin Edward ${ }^{2}$ \\ ${ }^{1}$ Research Scholar, Holy Cross College, Affiliated to Bharathidasan University, Trichy. \\ Email: jhobu@yahoo.co.in \\ ${ }^{2}$ Associate Professor E Research Advisor, Department of English, Holy Cross College, \\ Trichy
}

\begin{abstract}
The Psychological wavelengths intermingled in pursuance of roots of various characteristics as reflected through the novel Blindness are different conceptual explorations. Identity is an intricate term in the present scenario. For him, the novel is a medium where socio-cultural and political issues are addressed and his voice acts as a didactic language that represents the colonial and postcolonial subjects. Moreover, he illustrates the political ideology in a different way. The representation of the other by a meta-narrative voice is the hallmark of Jose Saramago's novels. In his novels, he acts as an all-knowing narrator or implied author who tries to transform the society and the Portuguese culture in general. The representation of the other in the novel Blindness is a kind of historical discourse which is articulated as artificial, a constructed category, a power-based and discriminatory construction. Of course, it is communicated through conventional, discursive and narrative strategies. Hence, we find a relation between history and story in these narratives. As so many disaster narratives start, Blindness also begins with a disaster-traffic jam. It anticipates a search for identity. In the novel, Saramago invites our attention to think of a kind of chaos and horror that happens in Blindness. In the novel Blindness, the identities clash with one another owing to the common identity of blindness having a big and tremendous impact in it one way or the other. In short, the significance of blindness becomes dominant only when there is eyesight and the existence of the nonblind. In that way, the blind have their own identity and culture and Saramago tries to add more coloring to that identity in a philosophical and eschatological manner. The paper intends to explain that idea.
\end{abstract}

Keywords: Blindness, Post Truth, Identity Crisis, Physical blindness, Spiritual blindness, Globalization and Localization

\section{INTRODUCTION}

Jose Saramago, the eminent and talented Portuguese writer and winner of the Nobel Prize for Literature passed away in 2010 and that was an unbridgeable gap in the literary world. He was 87 years old at that time. He died at his home in the Canary Islands where he moved after a great dispute with the Portuguese Government. He had his own identity as a committed writer and a prophetic spokesperson. Hence, he was honored in his homeland as a major cultural figure and a talented artist and moreover a committed literary genius. Unfortunately, he made enemies in his literary circle because of his identity as a committed communist and a bracket labeled atheist. We read that he was born into poverty in 1922 in a small village outside Lisbon. His parents were landless peasants who later moved to the city where Saramago had the opportunity to attend the (c) AesthetixMS 2019. This Open Access article is published under a Creative Commons Attribution Non-Commercial 4.0 International License (http://creativecommons.org/licenses/by-nc/4.o/), which permits non-commercial re-use, distribution, and reproduction in any medium, provided the original work is properly cited. For citation use the DOI. For commercial re-use, please contact editor@rupkatha.com. 
school. Eventually, he had to drop out due to lack of money and he switched over to another field of study to become a mechanic. It was also a futile attempt. It is through Margaret Jull Costa's voice we get his worldviews and his attachment with humanity in general. That is why the Prime minister of Portugal talked about him saying that 'his disappearance has left our culture poorer'. The search for identity is also a psychological one. It occurs due to the multiple identities which are synonymous with human life at present. Every now and then, our identities get transformed and altered because of the multicultural, multiethnic, multireligious, multilinguistic and multilateral society where we live in. The quick change in our identities is necessitated by our needs to fit in with the evolving circumstances we are in. Although, such adjustments would lead to our identities being sidelined in the course of time resulting in the inevitable conformity to a nasty uniform or homogenous way of life which goes in tandem with the dominant ideology. Even then, identities that are converged under a well-knit group can pave the way for the emergence of a social framework that is vibrant, lively and consolidated to the core.

\section{THE QUESTION OF IDENTITY IN THE NOVEL BLINDNESS}

The common link generated by the identity of blindness leads to many characters in the novel Blindness explores or delves deep into their multiple identities culminating in themselves finding out the hidden unconscious identities inherent in them. The doctor who goes blind is otherwise an individual not willing to come out of his own narrow realm where he is hemmed up with his own profession and its attendant problems. But when he is affected with blindness, the multiple identities in deep slumber within him come out into the open platform such as the ability to cope with the most atrocious situations in life, the metamorphosing into a being in the survival mode, the putting up of existential fight to eke out a living being reduced to the level of a beast, the organisational capacity shown to defend oneself against intractable problems and the courage displayed to take a fight to its eventual conclusion. The contraction of blindness keeps the situation in the space of wide-open nature moving the society towards the direction of coming out with an identity of non-compromising nature when it comes to the resolution of a problem. The identity of a society in a brutal state of affairs is amply demonstrated here with all stakeholders doing things going against the grain of humility and humanity. The heartless human souls obtain the identity of tender ones. The identity born out of institutionalization makes the foot soldiers within it to commit murders without any prick of consciousness. When people become part of a structured framework, they forget the cardinal or basic emotion ruling human society that is compassion, pity, and mercy towards fellow human beings. The novel offers a challenging commentary on the injustices of Portuguese society in particular and capitalist life in general. The meaning of the Portuguese word 'ensaio' is a test, a kind of rehearsal or an experiment. In fact, the Portuguese title for Blindness includes this word and it produces multiple meanings and even it represents multiple identities in connection with different characters of the novel. Moreover, Blindness is a test or an experiment that guides all of us to a world of anxiety, depression and even chaos. It also pauses a question of what would happen if we all become blind.

The final chapters of the novel Blindness guide the readers to a situation where we find that the characters ended up loitering through an apocalyptic world. The characters ended up feeling blind in their eyes and blind in feelings. Saramago's assessment of humanity is clearly articulated in the final chapters. In Blindness residents of an unidentified country additionally invokes a metaphorical identification and they may be struck through a transient epidemic of blindness and restricted to an intellectual or mental asylum, in which some people try to maintain ethical standards inside the face of this social collapse. Here blindness functions as a metaphor and the 
citizens are supplied as powerless. Metaphorically they're the colonized, oppressed and the marginalized class of human beings.

Blindness is Saramago's harrowing novel. It is originally published in the Portuguese language as Ensaio Sobre a Cegueira which means "Essay on Blindness". The emergence of new identities is a drift of the novel. Here the society is tormented by blindness and new societies are shaped by using blindness. The term identity does have deep-rooted meaning in the present juncture wherein even all aspects of life in our society are controlled by it. The assertive identity of today spills over into the realm of political, economic, social, religious, ethical and psychological fields of life. The marathon race to establish one's identity brings forth unexpected conflicts and tensions in our society. In the novel Blindness, the various characters are representatives of these variegated identities playing out one after another such as individuals struggling to reconcile with their surroundings, the confinement of people in a concentration camp type of situation and their woes in it, the diametrically opposed people trying to find a common thread to survive in this world, the chaotic structure of governance system that is built up parallel to one's identity and the fluctuations in the fortunate riding upon the backs of multiple identities.

\section{PSYCHOLOGICAL DRIVE OF IDENTITY}

The inner workings of the characters are presented as the psychologically driven identity crisis experienced by them. The occurrence of blindness is a self-imposed identity to escape from a world that is more blinded in the moral and ethical senses than the actual blindness that the human beings encounter. This blindness of psychological pedigree is deliberately created, intentionally absorbed and wantonly affected to the core. The two types of blindness presented in the novel are two extremes of identity running vertically. The physical blindness is meant to explore the unexplored and to know the pretentiously inclined and the other blindness is unconsciously implemented in the form of actions and reactions coming from the part of the powerful and the affluent or the opulent. Here, two modes of blindness try to achieve their own social acceptability in their own domains slowly but surely. The identity of blindness sheds light upon a few salient points such as identity as an undefined entity, identity caught up in the whirlpool of various ways of the society, identity as an established framework brimming to maintain an order and identity as a force of coercive nature prompting human beings to do things which in their normal circumstances they never think of doing. Even God is presented as a blind man in this novel. Whether God is blind concerning human suffering is a crucial question in the novel. In Saramago's viewpoint, God does not see human beings and their misery. Look at the following lines from Blindness:

Only God sees us, said the wife of the first blind man, who, despite disappointments and setbacks, clings to the belief that God is not blind to which the doctor's wife replies, Not even he...(265)

\section{THE SEARCH FOR IDENTITY AS A GLOBAL AND LOCAL PHENOMENON}

The question of identity has obtained an international dimension rather recently in which the true identity of an individual has come into the domain of a question mark because of the multiple identities so typical of humanity today. The questions who is global? and who is local? are very difficult to deal with or tackle head-on today because all are globalized locals in their identities, genders, customs, traditions, cultural heritages, sexualities, affiliations, and differences. 
So, globalized identity can't be erased from the personality of an individual. At the same time, the localized identity gets him to an overdrive wherein protectionism, nationalistic tendencies and aggressive identity politics come to become the mainstays of the society. Here, identity itself does have global and local connotations at the same time. It is global because of the interconnected, interrelated, intertwined, dovetailed and interdependent world in which we live. As a result of such an intermingled nature of the world, the global identity is a prerequisite for an individual, without which nothing can be taken to its eventual conclusion. The identity is local because through localized identification only, the real alienation felt through globalization can be ironed out adequately and aptly in the life of an individual. The localized assertions are signs of mitigation born out of aggressive and belligerent globalization pursued by global cooperates without taking into consideration the aspirations of the local environment, ecology, culture and ways of life. So, the very contention that certain literary trends can be encircled and bracketed does go against the general formulation regarding the description that literature is a globalized network of local realities finding their spaces in a world of many identities. In fact, identities become pluralistic dimensionalities propping up literature one way or the other. In the fold of literature, identities are storylines having a psychological grounding related to the author as well as the social, political, economic, moral and ethical realities of a nation.

When a nation reduces identity with respect to occidental or oriental scheme of things or religion or racial specifications, then identity instead of a pluralistic thing is driven by the pressing need of mobilizing people on the basis of narrow considerations that would destroy the secular fabric of a nation. If such mobilization is resorted to in the field of literature, it is tantamount to literature inhaling the air of intolerance. In the novel Blindness, such an overstretched identity is clearly pronounced to the core wherein globalized identity is so burdensome on the localized realities.

\section{GLOBALIZATION THROUGH LOCALIZATION VS LOCALIZATION THROUGH GLOBALIZATION-RECLAIMING OF IDENTITY IN THE NOVEL BLINDNESS}

The coinage, globalization through localization, signifies the dissemination of westernization that has got into the vitals of local manifold aspects, arenas, and walks of life. This trend is widespread and evocative from one end of the local domain to the other end. Today, the local areas in the farflung territories of the world do have the propensity to travel through the trajectory of globalization. This tendency is apparent in the local areas solely because of the networked world in which we live in. The fashionable trends and the viral videos so bandied about through the virtual world make the globalization through localization possible and an everyday reality fair and square. The blindness called globalization in the form of imitation or emulation is a reality unfolding everywhere in the world without any respite at present in the form of manipulated entities, systems, mechanisms, frameworks and institutionalized apparatus. In the novel Blindness, the enveloping of blindness is the aftereffect of a system striving hard to reassert its might over the hapless masses groaning under the weight of multiple identities.

The coinage, localization through globalization, brings forth the idea that the local trends get transformed into such a way that they go in tandem with globalization. The economic development of a locality is globalized in such a way that its capacity to find out solutions to local issues often gets mismatched and misrepresented. When localization is conducted through globalization, there are certain advantages such as the development of apps and technological know-how addressing local realities, the renewed focus given to local issues so that those issues do have a global resonance in the course of time and the patterned and methodological betterment of the society through the absorption of local expertise. In the novel Blindness, the 
local situation of blindness is highlighted to convey the message that a local issue does have global traction one way or the other. The localized and globalized realities do have their own spaces in this world of multiple and heterogeneous identities and pluralities. Allen Roger in the article "Jose Saramago: A Caverna", articulates the phenomenon of globalization. Look at the following lines:

In the Cave, Saramago is clearly presenting a kind of corporate brave new world where neoliberal globalization has transformed the society, and individuals are consumers in a world where nothing matters save the bottom-line. No one is responsible for what is happening -and many, like Marcal as especially his parents, welcome an antiseptic version of reality where living is synonymous with amusement and shopping. (112)

In the unconventional Blindness, Saramago tries to bring on the idea that human existence is subjected to humiliation, tortures, big insults and it is continually surrounded by way of lies and fake information. The universal lie has captured and forcefully grabbed the arena of reality and genuineness. It is also seen that men stopped respecting and accepting themselves. It is a feature of the post-truth world and it is also presented as a great post-modern cultural and intellectual shift. Saramago's version of globalization is completely negative and pessimistic. His phrases like " globalization will eat up the poor mouse of human rights", "globalization manufactures exclusion" and "faces of totalitarianism are many and globalization is one of them" ( Political affairs, 6) are thought-provoking and heart touching. Saramago through his novels very often connects the scaled-down voice of Portugal and this sense of inferiority conditions frequently reflects the cultural and psychological conditions the Portuguese people both at home and out of the country. The Year of the Death of Ricardo Reis is one of the masterpieces of Saramago and it is obviously one of the heteronyms of the famous Portuguese poet Fernando Pessoa, Portugal's most famous poet since Camoens. Psychologically the novel is treated as a quest to identify the spiritual roots stimulated by the desire to renew the unfinished and unethical life and art, reality, mirage, and hallucinations. Of course, there is often an ascent or conquest and consent or concurrence in his select novels and they reflect the psychological and metaphorical control or sway by ordinary people over their own lives and even the hierarchy. Moreover, Saramago's novels portray the conflict between light and darkness, and compassion and indifference. For him, meekness has to be imbibed and energized. He argues that a society without compassion is like a cemetery and it has to assimilate and consume these social values. He was actually trying to sermonize the issues from the voice of a communist thinker or narrator. Those sermons implicitly or explicitly cover up a communist utopia conceived by contemporary thought patterns. His novel Blindness offers a challenging commentary on the injustices of capitalist life to which society casts a blind eye. However, the novel provides a key to the physical appearance of the manuscript itself. For him, inward appearance counts more rather than outward appearance. In his The Gospel according to Jesus Christ, Saramago embarks on a quest to find what is at the back of things. Perhaps this is the most untouchable of all stories in the western world. Hence, it is a powerful worldly gospel that is poetic, provocative and blasphemous.

\section{CONCLUSION}

The concepts of blindness and insight are serious concerns of the novelist in the novel Blindness. It is through the character, doctor's wife, the reader is provided an added perspective of a bleak situation. Hence, she has a genuine identity that shapes the formation of other characters as well. Moreover, it is through the doctor's wife that the other characters discover one another and they 
search for a renewed identity where hope and optimism move hand in hand. A new understanding and a new lifestyle emerge and a new journey from the harshness of asylum to the world of humanity and empathy begins there.

\section{REFERENCES}

Abrams, M.H.,and Geoffrey Galt Harpham. Handbook of Literary Terms. (2009). New Delhi, India: Cengage Learning India Private Limited.

Saramago, Jose. Blindness. (1997). Translated from the Portuguese by Giovanni Pontiero. The Harvill Press.

The Cave. (2002). Translated from the Portuguese by Margaret Jull Costa. London, England: The Harvill Press.

The Gospel According to Jesus Christ. (1993). Translated from the Portuguese by Giovanni Pontiero. London, England: The Harvill Press.

"Political affairs: Interview with Jose Saramago, the author of Blindness". (2006).

http://www. Marxmail.org/archives/Marcho6/ saramago.htm Accessed: 25/o6/2019

Interview given to the London Daily Telegraph. (19 July 2002). Quoted by Paige Austin, in "Shadows on the Wall". Review of Jose Saramago's Novel The Cave. 